\title{
МОРФОМЕТРИЧНА ОЦІНКА ОСОБЛИВОСТЕЙ РЕМОДЕЛЮВАННЯ СТРУКТУР ПОРОЖНЬОЇ КИШКИ ПРИ РЕЗЕКЦІЯХ РІЗНИХ ОБ'ЄМІВ ПЕЧІНКИ
}

\section{○Л. В. Татарчук \\ ДВНз «Тернопільський державний медичний університет імені І. Я. Горбачевського мОз України»}

РЕзЮМЕ. Пострезекційна портальна гіпертензія, що виникає після видалення великих об'ємів паренхіми печінки, призводить до венозного застою та структурних змін в органах портальної системи. Адаптаційнокомпенсаторні процеси у травній системі при резекціях різних об' ємів печінки досліджені недостатньо.

Мета - кількісне морфологічне вивчення особливостей ремоделювання структур порожньої кишки при резекціях різних об'ємів печінки.

Матеріал і методи. Дослідження проведені на 43 статевозрілих щурах-самцях, які були поділені на 4 групи. 1 група нараховувала 12 інтактних тварин, 2 - 11 щурів після резекції 31,5\% паренхіми печінки, 3-12 тварин після резекції 42,0 \% о6' єму печінки, 4-8 щурів після резекції 58,1 \% печінки. Евтаназія дослідних тварин здійснювалася кровопусканням в умовах тіопенталового наркозу через 1 місяць від початку експерименту. Вирізані шматочки із порожньої кишки фіксували в 10 \% нейтральному розчині формаліну і після відповідного проведення через етилові спирти зростаючої концентрації заливали у парафінові блоки за загальноприйнятою методикою. Гістологічні зрізи товщиною 5-7 мкм після депарафінізації фарбували гематоксиліном-еозином, за ван-Гізон, Маллорі, Вейгертом, толуїдиновим синім. Морфометрично на гістологічних препаратах порожньої кишки визначали товщину слизової, м' язової, серозної оболонок та підслизового прошарку, довжину, ширину ворсинок, глибину, ширину крипт, висоту покривних епітеліоцитів, діаметр їх ядер, ядерно-цитоплазматичні відношення в епітеліоцитах, відносний о6'єм уражених епітеліоцитів, вираховували підслизово-слизовий та підслизовом'язовий індекси. Кількісні величини обробляли статистично.

Результати. Усестороннім аналізом отриманих морфометричних даних встановлено, що через місяць після резекції 31,5 \% паренхіми печінки вони змінювалися незначно. Після резекції 42 \% паренхіми печінки ремоделювання структур порожньої кишки було більш вираженим. У даних умовах експерименту нерівномірно та диспропорційно змінювалися морфометричні показники оболонок порожньої кишки, порушувалися відношення між ними, виникали патогістологічні зміни у стінці досліджуваного органа. Найбільш виражено зміненими виявилися морфометричні параметри порожньої кишки через місяць після резекції 58,1 \% паренхіми печінки. Нерівномірні зміни просторових характеристик оболонок кишки призводили до збільшення підслизовослизового індексу на 35,2 \%, а підслизово-м'язового - на 26,1%, кількості пошкоджених епітеліоцитів - у 30,5 раза, порівняно з контрольними морфометричними показниками.

Висновки. Резекція 42 \% паренхіми печінки та більше призводить до вираженого ремоделювання структур порожньої кишки, яке характеризується вираженими змінами морфометричних параметрів слизової, м'язової оболонок, підслизового прошарку, ворсинок, крипт, епітеліоцитів, порушенням співвідношень між просторовими характеристиками оболонок, ядром та цитоплазмою епітеліоцитів, істотним їх ураженням, що може призводити до дисфункції ушкодженого органа.

КлючОВІ СлОВА: порожня кишка; ремоделювання; резекція печінки.

Вступ. У хірургічних стаціонарах лікувальних закладів на сьогодні нерідко виконують резекцію печінки. Цю операцію здійснюють при доброякісних та злоякісних пухлинах, метастазах, травмах печінки, внутрішньопечінковому холангіолітіазі, альвеолярному ехінококозі, трансплантації печінки $[2,9,10]$. У сучасній медико-біологічній літературі зустрічаються публікації, де відображені результати експериментальних досліджень з вивчення паренхіми печінки при ії резекції. У той же час при вказаних операціях недостатньо досліджені структурні зміни у травному каналі. Вирішення даного питання має не тільки важливе теоретичне значення, а й набуває актуальності у клінічній практиці.

Резекція великих об'ємів паренхіми печінки призводить до виникнення пострезекційної портальної гіпертензії та складних загальнобіологіч- них процесів, які виникають і розвиваються при цьому в органах і системах організму при його адаптації до нового рівня життєдіяльності [10]. Необхідно зазначити, що детальне та об' єктивне знання компенсаторно-адаптаційних процесів у стінці порожньої кишки при резекціях різних об'ємів печінки, їхньої ролі у розвитку ентеральної недостатності до сьогоднішнього дня досліджені недостатньо і потребують вирішення.

Мета - кількісне морфологічне вивчення особливостей ремоделювання структур порожньої кишки при резекціях різних об' ємів печінки.

Матеріал і методи дослідження. Дослідження проведені на 43 статевозрілих щурах-самцях, які були поділені на 4 групи. 1 група нараховувала 12 інтактних практично здорових тварин, 2 - 11 щурів після резекції лівої бокової частки - 31,5 \% паренхіми печінки, 3 - 12 тварин після резекції лівої 
Огляди літератури, оригінальні дослідження, погляд на проблему

бокової і внутрішньої часток - 42,0% о6' єму печінки, 4 - 8 щурів після резекції правої та лівої бокових часток печінки (58,1 \%) [8]. Евтаназію дослідних тварин здійснювали кровопусканням в умовах тіопенталового наркозу через 1 місяць від початку експерименту. Усі маніпуляції та евтаназію щурів проводили з дотриманням основних принципів роботи з експериментальними тваринами відповідно до положення «Європейської конвенції про захист хребетних тварин, які використовуються для експериментальних та інших наукових цілей». (Страсбург, 1986 р.), «Загальних етичних принципів експериментів на тваринах», ухвалених Першим національним конгресом з біоетики (Київ, 2001 р.), а також Закону України «Про захист тварин від жорстокого поводження» (від 21.02.2006) [4].

Вирізані шматочки із порожньої кишки фіксували в $10 \%$ нейтральному розчині формаліну i після відповідного проведення через етилові спирти зростаючої концентрації заливали у парафінові блоки за загальноприйнятою методикою. Гістологічні зрізи товщиною 5-7 мкм після депарафінізації фарбували гематоксиліном-еозином, за ван-Гізон, Маллорі, Вейгертом, толуїдиновим синім [7]. Морфометрично на гістологічних препаратах порожньої кишки визначали товщину слизової (ТCO), м'язової (ТМО), серозної (ТсерО) оболонок та підслизового прошарку (ТПП), довжину (ДВ), ширину ворсинок (ШВ), глибину (ГК), ширину крипт (ШК), висоту покривних епітеліоцитів (ВПЕ), діаметр їх ядер (ДяЕ), ядерно-цитоплазматичні відношення (ЯЦВ) в епітеліоцитах, відносний об' $є$ м уражених епітеліоцитів (ВОУЕ). Вираховували при цьому підслизово-слизовий (ПСІ) та підслизовом'язовий (ПМІ) індекси відношенням меншої величини вимірюваних структур до більшої [1].

Кількісні величини обробляли статистично. Обробка результатів виконана у відділі системних статистичних досліджень Тернопільського державного медичного університету імені І. Я. Горбачевського в програмному пакеті Statsoft STATISTICA. Різницю між порівнюваними величинами визначали за критеріями Манна-Уїтні та Стьюдента [5].

Результати й обговорення. Отримані морфометричні параметри порожньої кишки представлені у таблиці 1. Усестороннім аналізом наведених у вказаній таблиці даних встановлено, що через місяць після резекції 31,5 \% паренхіми печінки вони змінювалися незначно. У даних умовах експерименту товщина слизової оболонки порожньої кишки зменшилися на 2,4 \%, а товщина м' язової оболонки - всього на 0,57\%. Товщина підслизового прошарку і серозної оболонки при цьому виявилися дещо збільшеними. Так, товщина підслизового прошарку у змодельованих експериментальних умовах зросла на 3,4 \%, а серозної оболонки - всього на 0,8 \%. Необхідно зазначити, що підслизово-слизовий індекс при цьому істотно не змінився, а підслизово-м' язовий індекс статистично достовірно $(p<0,05)$ зріс на $3,9 \%$.

Таблиця 1. Морфометрична характеристика порожньої кишки дослідних тварин (M $\pm m)$

\begin{tabular}{|c|c|c|c|c|}
\hline \multirow{2}{*}{ Показник } & \multicolumn{4}{|c|}{ Група спостереження } \\
\hline & 1 & 2 & 3 & 4 \\
\hline TCO, MKM & $390,8 \pm 7,2$ & $381,2 \pm 6,3$ & $345,7 \pm 4,5 * *$ & $334,1 \pm 3,6 * * *$ \\
\hline ТПП, мкм & $31,72 \pm 0,66$ & $32,80 \pm 0,63$ & $34,90 \pm 0,51$ ** & $36,60 \pm 0,45 * *$ \\
\hline TMO, MKM & $96,45 \pm 1,80$ & $95,90 \pm 1,20$ & $89,70 \pm 1,20 *$ & $88,10 \pm 0,81 * *$ \\
\hline TСерО, мкм & $6,23 \pm 0,12$ & $6,28 \pm 0,12$ & $6,50 \pm 0,07 *$ & $6,86 \pm 0,12 * *$ \\
\hline$\Pi \mathrm{Cl}$ & $0,0810 \pm 0,0009$ & $0,0840 \pm 0,0012$ & $0,1010 \pm 0,0008 * * *$ & $0,1095 \pm 0,0007 * * *$ \\
\hline ПMI & $0,329 \pm 0,006$ & $0,342 \pm 0,009 *$ & $0,390 \pm 0,006 * *$ & $0,415 \pm 0,007 * *$ \\
\hline ДВ,мКм & $219,7 \pm 1,8$ & $212,9 \pm 2,1^{*}$ & $185,7 \pm 2,4^{* * *}$ & $181,9 \pm 2,4^{* * *}$ \\
\hline ШВ, MKM & $56,9 \pm 1,2$ & $58,3 \pm 1,2$ & $63,72 \pm 1,2 *$ & $65,10 \pm 1,50 * *$ \\
\hline ГK, МKM & $105,8 \pm 1,2$ & $101,7 \pm 1,2^{*}$ & $88,5 \pm 1,2 * * *$ & $86,20 \pm 0,90 * * *$ \\
\hline ШК, мКM & $28,94 \pm 0,30$ & $30,10 \pm 0,33^{*}$ & $31,60 \pm 0,42 * *$ & $32,50 \pm 0,36 * * *$ \\
\hline ВПЕ, мКм & $12,65 \pm 0,15$ & $12,30 \pm 0,18$ & $10,70 \pm 0,18^{* * *}$ & $10,20 \pm 0,15^{* * *}$ \\
\hline ДЯЕ, мКМ & $3,92 \pm 0,03$ & $3,85 \pm 0,05$ & $3,97 \pm 0,07$ & $3,84 \pm 0,03 *$ \\
\hline ЯЦВ & $0,096 \pm 0,002$ & $0,098 \pm 0,003$ & $0,138 \pm 0,003 * * *$ & $0,142 \pm 0,04 * * *$ \\
\hline BОУЕ, \% & $2,12 \pm 0,03$ & $5,60 \pm 0,04 * * *$ & $38,90 \pm 0,54 * * *$ & $64,80 \pm 1,20 * * *$ \\
\hline
\end{tabular}

Примітка. * $-p<0,05 ;$ ** $-p<0,01 ; * * *-p<0,001$ порівняно з 1 групою спостережень.

Довжина ворсинок слизової оболонки порожньої кишки при видаленні лівої бокової частки печінки (31,5 \%) виявилася статистично достовірною $(p<0,05)$ зменшеною на $3,1 \%$, а їх ширина збільшилася на 2,5\%. Майже аналогічно змінюва- лися морфометричні параметри крипт. При цьому ширина крипт збільшилася на 4,0 \%, а їхня глибина зменшилася на $3,9 \%(p<0,05)$.

Висота покривних епітеліоцитів слизової оболонки дванадцятипалої кишки через місяць 
Огляди літератури, оригінальні дослідження, погляд на проблему

після резекції 31,5 \% паренхіми печінки статистично достовірно $(p<0,05)$ зменшилася на $2,8 \%$, а діаметр їх ядер - на 1,8 \%. Ядерно-цитоплазматичні відношення у цих клітинах суттєво не змінювалися, що свідчило про збереження стабільності структурного клітинного гомеостазу $[3,6]$. Відносний об' єм пошкоджених епітеліоцитів у контрольній групі тварин дорівнював $(2,12 \pm 0,03) \%$, а через місяць після видалення 31,5 \% паренхіми печінки - $(5,60 \pm 0,04) \%$. Остання цифрова величина 3 високим ступенем достовірності $(p<0,001)$ зросла у 2,6 раза, порівняно з аналогічною контрольною.

Урезультатіаналізуотриманихморфометричних параметрів встановлено, що через місяць після резекції 42 \% паренхіми печінки ремоделювання структур порожньої кишки було більш вираженим. У даних умовах експерименту товщина слизової оболонки статистично достовірно $(p<0,01)$ зменшилася на 11,5 , а м'язової - на 7,0 \%, порівняно з аналогічними параметрами 1 групи спостережень. Товщина підслизової основи при цьому збільшилася на $10,0 \%$, а серозної оболонки всього на 4,3 \%, порівняно з контрольними показниками. Зміненими у даних умовах експерименту виявилися підслизово-слизовий та підслизовом'язовий індекси. Так, підслизово-слизовий індекс порожньої кишки через місяць після резекції 42 \% паренхіми печінки з високою достовірністю ( $p<0,001)$ збільшився на $24,7 \%$ а підслизовом'язовий - на 18,5 \%. Деякі дослідники вважають, що при виражених змінах співвідношень між просторовими характеристиками оболонок порожнистих органів травної системи може виникати їх дисфункція [6].

Довжина ворсинок слизової оболонки дванадцятипалої кишки після місячного видалення $42 \%$ паренхіми печінки статистично достовірно $(p<0,001)$ зменшилася з $(219,7 \pm 1,8)$ мкм до $(185,7 \pm 2,4)$ мкм, тобто на $15,4 \%$, а глибина крипт - на $16,3 \%$. Ширина ворсинок слизової оболонки досліджуваного органа та ширина крипт при цьому відповідно зросли на 12,0 та 9,2\%. Нерівномірно, диспропорційно змінювалися при цьому морфометричні параметри епітеліоцитів та їх ядер, що призводило до порушення співвідношень між їх просторовими характеристиками. Описані зміни адекватно відображалися ядерно-цитоплазматичними відношеннями в цих клітинах. Цей морфометричний параметр в даних експериментальних умовах з високою достовірною різницею $(p<0,001)$ виявився збільшеним на $43,7 \%$, порівняно з аналогічним контрольним показником. Відносний об' єм пошкоджених епітеліоцитів при цьому зріс у 18,3 раза.

Найбільш виражено зміненилися морфометричні параметри порожньої кишки через місяць після резекції 58,1 \% паренхіми печінки. У даних умовах експерименту товщина слизової оболонки досліджуваного органа з високим ступенем достовірності $(p<0,001)$ зменшилася на $14,5 \%$, м'язової - на 8,6 \%. Товщина підслизового прошарку при цьому зросла на 15,4 \%, а серозної оболонки - на 10,1 \%. Підслизово-слизовий індекс виявився збільшеним на 35,2 \%, а підслизовом'язовий - на $26,1 \%$, порівняно з контрольними морфометричними показниками.

Довжина ворсинок слизової оболонки порожньої кишки та глибина крипт при цьому статистично достовірно $(p<0,001)$ зменшилися, відповідно на 17,2 та $18,5 \%$, а ширина ворсинок та крипт збільшилися - на 14,4 та 12,3 \%. Висота покривних епітеліоцитів слизової оболонки дванадцятипалої кишки через місяць після резекції 58,1 \% паренхіми печінки дорівнювала $(10,20 \pm 0,15)$ мкм. Ця цифрова величина з високою достовірністю $(p<0,001)$ виявилася меншою за аналогічний контрольний показник на 19,4 \%, а діаметр ядер цих клітин - на 2,0 \%. Ядерно-цитоплазматичні відношення у цих клітинах статистично достовірно $(p<0,001)$ зросли на $47,9 \%$, що свідчить про виражені порушення клітинного структурного гомеостазу $[1,3,6]$.

Необхідно зазначити, що через місяць після резекції 58,1 \% паренхіми печінки суттєво зріс відносний об' єм пошкоджених епітеліоцитів слизової оболонки порожньої кишки - $(64,80 \pm 1,20) \%$. Цей морфометричний параметр перевищував аналогічний показник 1 групи спостережень у 30,5 раза. Деякі дослідники вказують, що при такій кількості пошкоджених функціонуючих клітин слизової оболонки кишок може виникати ентеральна недостатність, тобто дисфункція органа $[1,6]$. Виявлені структурні зміни обумовлені видаленням значного о6' єму паренхіми печінки, вираженим зменшенням ії судинного русла, що призводить до гіпертензії у портальній системі. Розширення при цьому вен, що несуть кров у ворітну вену, їх виражене повнокрів'я супроводжуються гіпоксією, дистрофічними, некробіотичними змінами клітин та тканин, інфільтративними та склеротичними процесами у органах портальної системи $[10,11]$, що підтверджувалося світлооптичним дослідженням мікропрепаратів порожньої кишки дослідних тварин.

Так, при гістологічному дослідженні мікропрепаратів порожньої кишки тварин у 3 та 4 групах спостережень виявлені виражені судинні розлади (повнокрів'я переважно венозних судин, явища перивазального набряку, стази у венозній частині мікрогемоциркуляторного русла, осередки діапедезних крововиливів), дистрофічні, некробіотичні зміни епітеліоцитів, ендотеліоцитів судин, стромальних структур, інфільтративні та склеротичні процеси. Домінували описані па- 
Огляди літератури, оригінальні дослідження, погляд на проблему

тогістологічні зміни у стінці досліджуваного органа при резекції 58,1 \% паренхіми печінки. Варто також зазначити, що описані патогістологічні ушкодження стінки порожньої кишки при резекції печінки корелювали з такими відносними морфометричними параметрами, як підслизово-слизовий та підслизово-м' язовий індекси та ядерноцитоплазматичними відношеннями в епітеліоцитах.

Висновки. Резекція 42 \% паренхіми печінки та більше призводить до вираженого ремоделювання структур порожньої кишки, яке характеризується вираженими нерівномірними змінами

\section{ЛІТЕРАТУРА}

1. Автандилов Г. Г. Основы количественной патологической анатомии / Г. Г. Автандилов. - М. : Медицина, 2002. -240 c.

2. Вишневський В. А. Сегментарные резекции, отдаленные результаты при злокачественных опухолях печени / В. А. Вишневский, М. Г. Ефанов, И. В. Казаков // Укр. журнал хірургії. - 2012. - № 1 (16). - С. 5-15.

3. Гнатюк М. С. Особливості ядерно-цитоплазматичних відношень у епітеліоцитах слизової оболонки дванадцятипалої кишки / М. С. Гнатюк, Л. В. Татарчук, О. Б. Слабий // Науковий вісник Ужгородського університету. Серія "Медицина". - 2014. - Вип. 1 (49). С. 3-5.

4. Загальні етичні принципи експериментів на тваринах // Ендокринологія. - 2003. - Т. 8, № 1. - С. 142-145.

5. Лапач С. Н. Статистические методы в медико-биологических исследованиях Excell / С. Н. Лапач, А. В. Губенко, П. Н. Бабич. - К. : Морион, 2001. - 410 с.

6. Саркисов Д. С. Структурные основы адаптации и компенсации нарушенных функций / Д. С. Саркисов. М. : Медицина, 1998. -230 с.

\section{REFERENCES}

1. Avtandilov, G.G. (2002). Osnovy kolichestvennoy patologicheskoy anatomii [Basis of quantitative pathological anatomy]. Moscow: Meditsyna [in Russian].

2. Vishnievskii, V.A., Yefanov, M.G., \& Kazakov, I.V. (2012). Segmentarnyye rezektsyi, otdaliennyye rezultaty pri zlokachestvennykh opukholyakh piechyeni [Segmentar resections, long-term results in malignant liver tumors]. Ukr. zhurnal khirurhii - Ukrainian Journal of Surgery, 1, (16), 5-15 [in Russian].

3. Hnatiuk, M.S., Tatarchuk, L.V., \& Slabyi, O.B. (2014). Osoblyvosti yaderno-tsytoplazmatychnykh vidnoshen u epiteliotsytakh slyzovoi obolonky dvanadtsiatypaloi kyshky [Peculiarities of nuclear-cytoplasmic relations in epitheliocytes of mucosa of the duodenum]. Naukovyi visnyk Uzhhorodskoho universytetu. Seriia "Medytsyna" - Scientific Journal of Uzhhorod University. Series "Medicine", 1 (49), 3-5 [in Ukrainian].

4. Zahalni etychni pryntsypy eksperymentiv na tvarynakh [General ethical principles of experiments on морфометричних параметрів слизової, м'язової оболонок, підслизового прошарку, ворсинок, крипт, епітеліоцитів, порушенням співвідношень між просторовими характеристиками оболонок, ядром та цитоплазмою епітеліоцитів, істотним їх ураженням, що може призводити до дисфункції ушкодженого органа.

Перспективи подальших досліджень. Всебічне адекватне вивчення особливостей ремоделювання структур порожньої кишки в умовах пострезекційної портальної гіпертензії дозволить суттєво поліпшити діагностику, корекцію та профілактику досліджуваної патології.

7. Сорочинников А. Г. Гистологическая и микроскопическая техника / А. Г. Сорочинников, А. Е. Доросевич. - М. : Медицина. -2007. - 448 с.

8. Татарчук Л. В. Масометрична характеристика часток печінки дослідних тварин / Л. В. Татарчук // XIX Міжнародний медичний конгрес студентів та молодих вчених, присвячений пам' яті ректора члена-кореспондента НАМН України, професора Леоніда Якимовича Ковальчука, 27-29 квітня 2015 р. : матер. конгр. - Тернопіль : ТДМУ, 2015. - С. 333.

9. Федоров В. Д. Основные осложнения обширных резекций печени и пути их предупреждения / В. Д. Федоров, В. А. Вишневский, Н. А. Назаренко // Бюлл. сибирской медицины. - 2007. - № 4. - С. 16-24.

10. Nanashima A. A. modified grading system for post-hepatectomy metastatic liver cancer originating form colorectal carcinoma / A. Nanashima, Y. Sumida, T. Abo // J. Surg. Oncol. - 2008. - No. 98. - P. 363-370.

11. Takase $S$. Venosus hypertension, inflammation and valve remodeling / S. Takase, L. Parcarella, L. Lerond // Eur. J. Vasc. Endovasc. Surg. - 2004. - Vol. 28, No. 5. - P. 484-493.

animals]. (2003). Endokrynolohiia - Endocrinology, 8, 1, 142-145 [in Ukrainian].

5. Lapach, S.N., Gubenko, A.V. \& Babich, P.N. (2001). Statistichieskiie metody $v$ mediko-biologicheskikh issledovaniyakh Excell [Statistical methods in medicobiological investigations Excell]. Kyiv: Morion [in Russian].

6. Sarkisov, D.S. (1998). Strukturnye osnovy adaptatsyi i kompensatsyi narushennykh funktsyy [Structural basis adaptation and compensation damage function]. Moscow: Meditsyna [in Russian].

7. Sorochinnikov, A.G., \& Dorosyevich, A.Ye. (2007). Gistologichieskaya i mikroskopicheskaya tiekhnika [Histological and microscopic equipments]. Moscow: Meditsyna [in Russian].

8. Tatarchuk, L.V. (2015). Masometrychna kharakterystyka chastok pechinky doslidnykh tvaryn [Massometrical characteristics of liver parts in experimental animals]. KHIKH Mizhnarodnyi medychnyi konhres studentiv ta 
Огляди літератури, оригінальні дослідження, погляд на проблему

molodykh vchenykh, prysviachenyi pamiati rektora chlenakorespondenta NAMN Ukrainy, profesora L.Ya. KovalchukaXIX International Medical Congress of Students and Young Scientists, devoted to the memory of correspondent member of the NAMS professor L.Ya. Kovalchuk. April 27-29. - congress materials, 333 [in Ukrainian].

9. Fiodorov, V.D., Vishnievskiy, V.A., \& Nazaryenko, N.A. (2007). Osnovnye oslozhnieniya obshyrnykh rezektsyy pecheni i puti ikh preduprezhdeniya [The main complications of extensive liver resections and ways to prevent

them]. Byull. Sibirskoy meditsyny - Journal of Siberian Medicine, 4, 16-24 [in Russian].

10. Nanashima, A., Sumida, Y., \& Abo, T. (2008). A modified grading system for post-hepatectomy metastatic liver cancer originating form colorectal carcinoma. J. Surg. Oncol., 98, 363-370.

11. Takase, S., Parcarella, L., Lerond, L. (2004). Venosus hypertension, inflammation and valve remodeling. Eur. J. Vasc. Endovasc. Surg., 28, 5, 484-493.

\title{
МОРФОМЕТРИЧЕСКАЯ ОЦЕНКА ОСОБЕННОСТЕЙ РЕМОДЕЛИРОВАНИЯ СТРУКТУР ТОЩЕЙ КИШКИ ПРИ РЕЗЕКЦИЯХ РАЗНЫХ ОБЪЕМОВ ПЕЧЕНИ
}

\author{
Гвуз «Тернопольский государственный медицинский университет имени И. Я. Горбачевского \\ МЗ Украины»
}

РЕЗЮМЕ. Пострезекционная портальная гипертензия, возникающая после удаления больших объемов паренхимы печени, приводит к венозному застою и структурным изменениям в органах портальной системы. Адаптационно-компенсаторные процессы в системе пищеварения при резекциях разных объемов печени исследованы недостаточно.

Цель - количественное морфологическое изучение особенностей ремоделирования структур тощей кишки при резекциях разных объемов печени.

Материал и методы. Исследования проведены на 43 половозрелых крысах-самцах, которые были поделены на 4 группы. 1 группа насчитывала 12 интактных животных, 2 - 11 крыс после резекции 31,5 \% паренхимы печени, 3-12 животных после резекции 42,0 \% объма печени, 4- 8 крыс после резекции 58,1 \% печени. Эвтаназию исследуемых животных осуществляли кровопусканием в условиях тиопенталового наркоза через 1 месяц от начала эксперимента. Вырезанные кусочки из тощей кишки фиксировали в 10 \% нейтральном растворе формалина и после соответствующего проведения в этиловых спиртах возростающей концентрации заливали парафином. Гистологические срезы толщиной 5-7 мкм после депарафинизации красили гематоксилином-эозином, по ван-Гизон, Маллори, Вейгерту, толуидиновым синим. Морфометрически на гистологических препаратах тощей кишки определяли толщину слизистой, мышечной, серозной оболочек и подслизистого слоя, длину, ширину ворсинок, глубину, ширину крипт, высоту покровных эпителиоцитов, диаметр их ядер, ядерно-цитоплазматические соотношения в эпителиоцитах, относительный объем поврежденных эпителиоцитов, вычисляли подслизисто-слизистый и подслизисто-мышечный индексы. Количественные величины обрабатывали статистически.

Результаты. В результате анализа полученных морфометрических данных выявлено, что через месяц после резекции 31,5 \% паренхимы печени они изменялись незначительно. После резекции 42 \% паренхимы печени ремоделирование структур тощей кишки было более выраженным. В этих условиях эксперимента неравномерно и диспропорционально изменялись морфометрические показатели оболочек тощей кишки, нарушались соотношения между ними, возникали патогистологические изменения в стенке исследуемого органа. Наиболее выраженно измененными были морфометрические параметры тощей кишки через месяц после резекции 58,1 \% паренхимы печени. Неравномерные изменения просранственных характеристик оболочек кишки приводили к увеличению подслизисто-слизистого индекса на 35,2 \%, подслизисто-мышечного - на 26,1 \%, количества поврежденных эпителиоцитов - в 30,5 раза, по сравнению с контрольными морфометрическими показателями.

Выводы. Резекция 42 \% и больше паренхимы печени приводит к выраженному ремоделированию структур тощей кишки, которое характеризуется выраженными неравномерными изменениями морфометрических параметров слизистой, мышечной оболочек, подслизистого слоя, ворсинок, крипт, эпителиоцитов, нарушением соотношений между пространственными характеристиками оболочек, ядром и цитоплазмой эпителиоцитов, существенным их повреждением, что может приводить к дисфункции поврежденного органа.

КЛЮЧЕВЫЕ СЛОВА: тощая кишка; ремоделирование; резекция печени. 


\section{Огляди літератури, оригінальні дослідження, погляд на проблему \\ MORPHOMETRICAL EVALUATION OF REMODELING PECULIARITIES OF JEJUNUM STRUCTURES AT RESECTIONS OF LIVER DIFFERENT VOLUMES}

\section{@L. V. Tatarchuk}

\section{Horbachevsky Ternopil State Medical University}

SUMMARY. Postresection portal hypertension, which occurs after the removal of large volumes of liver parenchyma, leads to venous congestion and structural changes in the organs of the portal system. Adaptive-compensatory processes in the digestive system after resection of different volumes of the liver are insufficiently studied.

The aim is quantitative morphological study of the features of remodeling structures of the jejunum at resection of different volumes of the liver.

Material and Methods. The studies were conducted on 43 sexually mature male rats, which were divided into 4 groups. The 1 st group consisted of 12 intact animals, 2 nd -11 rats after resection of $31.5 \%$ of liver parenchyma, 3rd - 12 animals after resection of $42.0 \%$ of the liver volume, 4 th -8 rats after resection $58.1 \%$ of liver. Euthanasia of experimental animals was carried out by bloodletting in conditions of thiopental anesthesia 1 month after the beginning of the experiment. The cut pieces from the jejunum were fixed in a $10 \%$ neutral formalin solution, and after appropriate conduction, ethyl alcohol of increasing concentration was poured in paraffin blocks according to the generally accepted method. Histologic sections 5-7 um thick after deparaffinization were stained with hematoxylin-eosin, for van Gizon, Mallory, Weigert, and toluidine blue. Morphometrically on the histological preparations of the jejunum, thickness of the mucous, muscle, serous membranes and submucosal layer, length, width of villi, depth, width of crypts, height of cover epithelial cells, diameter of their nuclei, nuclear-cytoplasmic relations in epitheliocytes, relative volume of the affected epithelial cells, calculate submucosal-mucous and submucosal-muscular indices. Quantitative values were processed statistically.

Results and Discussion. All-round analysis of the obtained morphometric data showed that they changed slightly after a month after resection of $31.5 \%$ of liver parenchyma. After resection $42 \%$ of the liver parenchyma of the remodeling of the jejunum structures was more pronounced. In these experimental conditions, morphometric indices of the jejunum membranes were unevenly and disproportionately altered, relations between them were violated, pathological changes in the wall of the organ under investigation were observed. The morphometric parameters of the jejunum in the month after resection of $58.1 \%$ of liver parenchyma were the most pronounced changes. Uneven changes in the spatial characteristics of the intestinal mucosa resulted in an increase in submucosal-mucous index of $35.2 \%$, and submucosal-muscle - by $26.1 \%$, the number of damaged epithelial cells - 30.5 times compared with control morphometric indices.

Conclusions. Resection of $42 \%$ or more of the liver parenchyma leads to a marked remodeling of the structures of the jejunum, which is characterized by pronounced changes in the morphometric parameters of the mucosa, muscle membranes, submucosal layers, villi, crypt, epitheliocytes, violation of the relationships between spatial characteristics of the shells, the nucleus and cytoplasm of the epithelial cells, significant their lesion, which can leads to dysfunction of the damaged organ.

KEY WORDS: jejunum; remodeling; resection of liver. 